\title{
Prevalence of major HIV- risk related behaviour among SSS3 students in Port Harcourt Metropolis, Nigeria
}

\author{
Abiola A. Aomreore and Edward A.D. Alikor* \\ University of Port Harcourt Teaching Hospital, Port Harcourt \\ *Address for correspondence: Dr Edward AD Alikor; E-mail: Achi Alikor@yahoo.com; Telephone: \\ +23408033097515
}

\begin{abstract}
SUMMARY
The paper intended to find the prevalence of HIV infection risk-related behaviours among third year senior secondary school students in Port Harcourt metropolis. A cross-sectional survey among 1800 third year senior secondary school students randomly selected from thirteen secondary schools in Port Harcourt metropolis was done using two-stage sampling technique. Demographic data and information on the sexual behaviour of each student in the study group was obtained from self-administered structured questionnaire. The prevalence of sexual intercourse was $61.1 \%$. Males were more sexually active than females. Age of first sexual intercourse was 13.2 \pm 5.6 years for males and 13.9 \pm 4.1 years for females. Of the sexually active students, $32.6 \%$ had multiple sexual partners. Sexual activity of the students did not increase with age. The prevalence of Intravenous drug use (IVDU) was found to be $1.4 \%$. The use of intravenous drugs was more among the males $(80.8 \%)$ than among the females. The prevalence of blood transfusion is $10.3 \%$. Among the sexually active students only $437(36.9 \%)$ used condom. Sex of student, social class and school gender were significant predictors of ever-had sexual activity. The paper concludes that the prevalence of sexual behaviour related to the development of HIV/AIDS amongst the students is high. The need to highlight HIV/AIDS education programmes in the school curriculum of adolescents is discussed.
\end{abstract}

[Afr J Health Sci. 2008; 15:42-49]

\section{Introduction}

Two-thirds of the world's total number of people living with HIV reside in sub-Saharan Africa [1,2]. Sixty percent of all AIDS cases and majority of the new infections are seen in 15-24 year olds ${ }^{1}$. Adolescence is the time during which behavioural changes that transform a child into an adult occur. Adolescents are particularly vulnerable to HIV because the major risk factors of HIV transmission are common and mostly initiated in adolescence $[1,3,4]$. They are sexually active, generally do not have a stable sexual relationship [1,4,5] and often ignorant of the health risks of their sexual behaviour. They tend to be sensitive and subject to control by peer pressures. Some of the adolescents may be sexually exploited by adults $[4,6]$. Those who engage in intravenous drug use (IVDU) are even more vulnerable to sex- or injectionrelated HIV transmission [6]. Adolescents generally find it difficult to reach health facilities where they can discuss questions related to sexual health. Counselling is rarely available and family planning clinics are mostly restricted to married women and couples. Adolescents are usually reluctant to talk to doctors and parents due to embarrassment and fear of possible lack of respect of their confidentiality $[1,3,7]$. As they are still developing behaviour and experimenting in sexual matters, they can adopt safer practices from the onset. Their attitudes are usually less rigid and with less entrenched taboos, they can be channelled positively towards AIDS education programmes to spread messages on what is 
safe and what is not. If they are successfully counselled, they can stay free of HIV and form a reservoir of potential healthy parents $[1,3,7]$. In order to have the basis on which to plan health education strategies on HIV control and prevention, the prevalence and pattern of HIV infection risk-related behaviour among adolescents is essential. This study therefore set out to find the prevalence of HIV infection risk-related behaviours among third year senior secondary school students in Port Harcourt metropolis.

\section{Materials and Methods}

The study was conducted in the metropolis Port Harcourt, in the Niger delta region of Nigeria. The subjects were 1,930 third (final) year senior secondary school students from 13 government approved secondary schools. This sample size meets the estimate of 1,500 required to determine a prevalence of sexual intercourse of $29 \%[8,9]$ with an absolute precision of $2.25 \%$ at $95 \%$ confidence. The study was ethically cleared and approved by relevant school authorities. A two-stage stratified sampling method was used to select the thirteen schools. The details of the sampling method have been stated in a previous publication [10].

Pre-tested structured questionnaires were used to collect demographic and medical information as well as information of the sexual behaviour of the study group. The data was analysed using Statistical Package for Social Science (SPSS) for Window 7.5. The descriptive statistics were obtained. Sexual risk status was computed based on number of sexual partners and classified into two categories: low-risk sexual status, consisting of students with only one sexual partner; and high-risk sexual status consisting of students with more than one sexual partner.

\section{Results}

One thousand nine hundred and thirty (1930) students participated in the study. Data from 1800 students were analysed. Information from $130(6.7 \%)$ students who completed the questionnaires wrongly was not included in the analysis. The mean age of the males was $16.59 \pm 1.53$ years and that of the females was $16.82 \pm 1.62$ years.
Table 1 shows distribution ever-had sexual intercourse of the study group by age and sex. Overall, the prevalence of ever-had sexual intercourse was $61.1 \%$. Males were more sexually active than females with a prevalence of $53.2 \%$ compared to $46.2 \%$ in females. Nine hundred and seventy four $(61 \%)$ of the students aged $\leq 18$ and $126(65 \%)$ of students aged $>18$ years admitted to be sexually active. Sexual activity of the students did not increase with age.

Table 2 shows the prevalence of IVDU to be $1.4 \%$. The use of intravenous drugs was more among the males $(80.8 \%)$ than among the females (19.2\%). None of the students reported the sharing of needles. The prevalence of blood transfusion is $10.3 \%$ as shown in Table 3. Majority (62.4\%) of the students who had blood transfusion in the past were females. Among the students who claimed to be sexually active, $13.8 \%$ admitted having sexual intercourse rarely, $45.3 \%$ occasionally, $8.9 \%$ frequently, $1.5 \%$ had sex daily, while $30.6 \%$ did not respond to the question (Table 4). Table 5 shows the age distribution at first sexual intercourse for males and females. One thousand and forty $(94.7 \%)$ of the 1100 sexually active students could remember their ages at first sexual intercourse. About $0.2 \%$ of the students gave ambiguous answers while $4.9 \%$ did not answer the question. Most (70\%) of the students had first sexual intercourse between 13 and 16 years. Mean age of first sexual intercourse was $13.2 \pm 5.6$ years for males and $13.9 \pm 4.1$ years for females. By the time the students were 18 years of age $89.8 \%$ of them had been sexually exposed.

Six hundred and forty students (58.2\%) reported that they had only one sexual partner in their lifetime while 359 (32.6\%) had more than one partner. The distribution of sexual risk with age is shown in Table 6. One hundred and one $(9.2 \%)$ of the sexually active students did not respond to the question. The sexual partners for $765(69.5 \%)$ of the sexually active students, were fellow students. One hundred and eighty three $(16.6 \%)$ had sexual intercourse with much older adults. Eight respondents $(0.7 \%)$, all boys, admitted that their sexual partners were commercial sexual workers, $18(1.6 \%)$ reported intercourse with their relatives (uncles, cousins and stepfather) while $11.5 \%$ (126) did not indicate whom they 
had sex with. Among the sexually active students only 437 (36.9\%) used condom.

The results of the multiple and stepwise regression analysis for the sexual activity of the students are presented in Tables $7 \mathrm{a}$ and $7 \mathrm{~b}$ respectively. Table $7 \mathrm{a}$ shows that of the entire variables studied sex; social class and school gender were significant predictors of ever-had sexual activity and with other variables accounting for $11.2 \%$ of the variation in ever-had sexual activity. Table $7 \mathrm{~b}$ shows that school proprietorship alone accounted for $8.4 \%$ of the variation, school gender and sex of student accounted for $1.1 \%$ and $0.8 \%$ respectively.

Table 1: Age and sex distribution of the students by sexual activity

\begin{tabular}{|c|c|c|c|c|}
\hline Age & $\begin{array}{l}\text { Total No. } \\
\text { students in the age } \\
\text { group }\end{array}$ & Male & $\begin{array}{l}\text { ally active } \\
\text { Females }\end{array}$ & Total (\%) \\
\hline 13 & 7 & 3 & 2 & $5(71.4)$ \\
\hline 14 & 55 & 16 & 16 & $32(58.2)$ \\
\hline 15 & 335 & 122 & 81 & 203 (60.6) \\
\hline 16 & 487 & 167 & 135 & $302(62.0)$ \\
\hline 17 & 470 & 143 & 129 & $272(57.9)$ \\
\hline 18 & 252 & 71 & 89 & $160(63.5)$ \\
\hline 19 & 122 & 36 & 42 & 78 (63.9) \\
\hline 20 & 31 & 15 & 6 & $21(67.7)$ \\
\hline 21 & 8 & 4 & 1 & $5(62.5)$ \\
\hline 22 & 17 & 7 & 4 & $11(64.7)$ \\
\hline 23 & 13 & 1 & 7 & 8 (61.5) \\
\hline 24 & 1 & 0 & 1 & $1(100)$ \\
\hline & 2 & 0 & 2 & $2(100)$ \\
\hline Total & & $\begin{array}{l}585 \\
(53.2 \%)\end{array}$ & $\begin{array}{l}515 \\
(46.8 \%)\end{array}$ & $1100(61.1 \%)$ \\
\hline
\end{tabular}

Table 2: Age and sex distribution of the students who reported the use of intravenous drugs

\begin{tabular}{lllllll}
\hline \multirow{2}{*}{$\begin{array}{l}\text { Age } \\
\text { (years) }\end{array}$} & No. of & \multicolumn{2}{l}{$\begin{array}{l}\text { Males } \\
\text { Students }\end{array}$} & \multicolumn{2}{l}{$\begin{array}{l}\text { Fespondents } \\
\text { resposends }\end{array}$} & \multicolumn{2}{l}{$\begin{array}{l}\text { Total } \\
\text { respondents } \\
\text { responses to }\end{array}$} & 'Yes' \\
& & & 'Yes' & No & 'Yes' & IVDU \\
& & & & & & \\
\hline 13 & 7 & 4 & 0 & 3 & 0 & 0 \\
14 & 55 & 30 & 0 & 25 & 0 & 0 \\
15 & 335 & 200 & 4 & 135 & 0 & 4 \\
16 & 487 & 261 & 3 & 226 & 3 & 6 \\
17 & 470 & 232 & 3 & 238 & 2 & 5 \\
18 & 252 & 116 & 3 & 136 & 0 & 3 \\
19 & 122 & 58 & 3 & 64 & 0 & 3 \\
20 & 31 & 21 & 5 & 10 & 0 & 5 \\
21 & 8 & 5 & 0 & 3 & 0 & 0 \\
22 & 17 & 8 & 0 & 9 & 0 & 0 \\
23 & 13 & 4 & 0 & 9 & 0 & 0 \\
24 & 1 & 0 & 0 & 1 & 0 & 0 \\
25 & 2 & 0 & 0 & 2 & 0 & 0 \\
\hline Total & $\mathbf{1 , 8 0 0}$ & $\mathbf{9 3 9}$ & $\mathbf{2 1}$ & $\mathbf{8 6 1}$ & $\mathbf{5}$ & $\mathbf{2 6 ( 1 . 4 \% )}$ \\
\hline
\end{tabular}


Table 3: Age and sex distribution of the students with blood transfusion history

\begin{tabular}{lllllll}
\hline $\begin{array}{l}\text { Age } \\
\text { (years) }\end{array}$ & $\begin{array}{l}\text { No. of } \\
\text { Students }\end{array}$ & $\begin{array}{l}\text { Males respondent to } \\
\text { Blood } \\
\text { history }\end{array}$ & $\begin{array}{l}\text { Females respondent } \\
\text { transfusion }\end{array}$ & $\begin{array}{l}\text { Total 'Yes' } \\
\text { to Blood transfusion } \\
\text { history }\end{array}$ & $\begin{array}{l}\text { responses } \\
\text { Blood } \\
\text { transfusion } \\
\text { history }\end{array}$ \\
& & No & 'Yes' & No & 'Yes' & \\
13 & 7 & 4 & 0 & 3 & 0 & 0 \\
14 & 55 & 30 & 2 & 25 & 3 & 5 \\
15 & 335 & 200 & 9 & 135 & 17 & 26 \\
16 & 487 & 261 & 9 & 226 & 21 & 30 \\
17 & 470 & 232 & 14 & 238 & 26 & 40 \\
18 & 252 & 116 & 8 & 136 & 9 & 17 \\
19 & 122 & 58 & 15 & 64 & 19 & 34 \\
20 & 31 & 21 & 6 & 10 & 8 & 14 \\
21 & 8 & 5 & 1 & 3 & 2 & 2 \\
22 & 17 & 8 & 4 & 9 & 3 & 7 \\
23 & 13 & 4 & 3 & 9 & 5 & 8 \\
24 & 1 & 0 & 0 & 1 & 1 & 1 \\
25 & 2 & 0 & 0 & 2 & 2 & 2 \\
Total & $\mathbf{1 , 8 0 0}$ & $\mathbf{9 3 9}$ & $\mathbf{7 1}$ & $\mathbf{8 6 1}$ & $\mathbf{1 1 6}$ & $\mathbf{1 8 6}(\mathbf{1 0 . 3 \%})$ \\
\hline
\end{tabular}

Table 4: Frequency of sexual intercourse by age of the sexually active students

\begin{tabular}{|c|c|c|c|c|c|}
\hline \multirow{2}{*}{$\begin{array}{l}\text { Age } \\
\text { (years) }\end{array}$} & \multicolumn{4}{|c|}{ Frequency of sex } & \multirow[t]{2}{*}{ Total } \\
\hline & Daily & Frequently & Occasional & Rarely & \\
\hline 13 & 0 & 0 & 3 & 0 & $5(0.5 \%)$ \\
\hline 14 & 0 & 7 & 9 & 3 & $22(2.2 \%)$ \\
\hline 15 & 4 & 19 & 91 & 28 & 193 \\
\hline 16 & 1 & 30 & 149 & 45 & $(19.3 \%)$ \\
\hline 17 & 5 & 20 & 125 & 36 & 284 \\
\hline 18 & 2 & 12 & 69 & 22 & $(28.4 \%)$ \\
\hline 19 & 0 & 7 & 33 & 12 & 242 \\
\hline 20 & 2 & 1 & 10 & 4 & $(24.2 \%)$ \\
\hline 21 & 0 & 1 & 3 & 1 & 140 \\
\hline 22 & 0 & 0 & 4 & 1 & $(14.0 \%)$ \\
\hline 23 & 2 & 0 & 2 & 0 & $71(7.1 \%)$ \\
\hline 24 & 0 & 0 & 0 & 0 & $20(2.0 \%)$ \\
\hline \multirow[t]{5}{*}{25} & 0 & 1 & 0 & 0 & $5(0.5 \%)$ \\
\hline & & & & & $70.7 \%)$ \\
\hline & & & & & $7(0.7 \%)$ \\
\hline & & & & & $1(0.1 \%)$ \\
\hline & & & & & $2(0.2)$ \\
\hline Total & $16(1.5 \%)$ & $98(8.9 \%)$ & $498(45.3 \%)$ & $152(13.8 \%)$ & $\begin{array}{l}999 \\
(100 \%)\end{array}$ \\
\hline
\end{tabular}


Table 5: Age at first sex of the sexually active students

\begin{tabular}{llll}
\hline Age & SEX & Female & Total \\
& Male & 3 & $7(0.67 \%)$ \\
\hline 8 & 4 & 8 & $26(2.5 \%)$ \\
9 & 18 & 9 & $28(2.69 \%)$ \\
10 & 19 & 6 & $16(1.54 \%)$ \\
11 & 10 & 24 & $67(6.44 \%)$ \\
12 & 43 & 108 & $214(20.54 \%)$ \\
13 & 106 & 78 & $168(16.15 \%)$ \\
14 & 90 & 114 & $215(20.67 \%)$ \\
15 & 101 & 81 & $185(17.79 \%)$ \\
16 & 74 & 45 & $91(8.75 \%)$ \\
17 & 46 & 18 & $37(3.56 \%)$ \\
18 & 19 & 6 & $11(1.06 \%)$ \\
19 & 5 & 1 & $2(0.19 \%)$ \\
20 & 1 & 2 & $2(0.19 \%)$ \\
21 & 0 & 0 & 0 \\
22 & 0 & 0 & 0 \\
23 & 0 & 0 & 0 \\
24 & 0 & 0 & $1(0.10 \%)$ \\
25 & 1 & $\mathbf{5 0 3}(\mathbf{4 8 . 4 \% )}$ & $\mathbf{1 0 4 0}(\mathbf{1 0 0} \%)$ \\
Total & $\mathbf{5 3 7}(\mathbf{5 1 . 6 \% )}$ & & \\
\hline
\end{tabular}

Table 6: Sexual risk behaviour of the sexually active students by age

\begin{tabular}{llll}
\hline \multicolumn{4}{l}{ No. of sexual partners } \\
Low sexual risk & High sexual risk & Total \\
\hline 13 & 5 & 0 & $5(0.5 \%)$ \\
14 & 20 & 9 & $29(2.9 \%)$ \\
15 & 138 & 46 & $184(18.4 \%)$ \\
16 & 220 & 75 & $295(29.5 \%)$ \\
17 & 106 & 119 & $225(22.5 \%)$ \\
18 & 71 & 58 & $129(12.9 \%)$ \\
19 & 50 & 28 & $78(7.8 \%)$ \\
20 & 5 & 16 & $21(2.1 \%)$ \\
21 & 8 & 2 & $10(1.0 \%)$ \\
22 & 6 & 2 & $8(0.8 \%)$ \\
23 & 8 & 4 & $12(1.2 \%)$ \\
24 & 1 & 0 & $1(0.1 \%)$ \\
25 & 2 & 0 & $2(0.2 \%)$ \\
\hline Total & $\mathbf{6 4 0 ( 5 8 . 2 \% )}$ & $\mathbf{3 5 9 ( 3 2 . 6 \% )}$ & $\mathbf{9 9 9}(\mathbf{1 0 0 \% )}$ \\
\hline
\end{tabular}

\section{Discussion}

The prevalence of sexual intercourse of $65.8 \%$ found in this study is similar to results from a previous study by Judith et al [11] who reported prevalence of $63.5 \%$ but lower than the prevalence of up to eighty percent found by other workers in Cameroon and Nigeria reported $[12,13]$. Lower prevalence of everhad sexual intercourse in adolescents of 29 to $35 \%$ has been found by other workers in
Nigeria $[8,9,14]$. Younger average age of the study group, smaller sample sizes of many of the other studies and the reluctance of the adolescent to admit pre-marital sex (which will partly depend on the method, and the environment, of administration of the questionnaire) may explain the lower prevalence obtained in these studies. 
The more adventurous nature of boys compared to girls, often engaging in sexual relationships merely for sexual experience, may explain increased sexual activity than girls as found in this study, which is also similar to finding from previous studies by Meeker et al [12] and Olufunmilayo et al [14]. The low prevalence of intravenous drug use $(1.4 \%)$ is not surprising as studies by Adelekan [15] and Ogunremi [16] found comparable prevalence of intravenous drug use between $1.2 \%$ and $4.9 \%$. Anochie et al [17] did not find any case of IVDU among the students studied in the same locality as the present study. In contrast, higher (35.6\%) prevalence of IVDU has been reported in more developed countries [18]. The higher prevalence of IVDU among boys found in this study is similarly to data from previous studies $[17,19]$.

Table 7a: Relationship between sexual activity and some variables using multiple regression

\begin{tabular}{|c|c|c|c|}
\hline $\begin{array}{l}\text { Variable } \\
(\text { Constant }=0.979)\end{array}$ & $\begin{array}{l}\text { Regression } \\
\text { coefficient }\end{array}$ & $P$ value & $P$ significant \\
\hline Age & 0.005 & 0.838 & $>0.05$ \\
\hline Sex & 0.1000 & 0.000 & $<0.05^{*}$ \\
\hline Social class & 0.106 & 0.000 & $<0.05^{*}$ \\
\hline School gender & 0.162 & 0.000 & $<0.05^{*}$ \\
\hline $\begin{array}{l}\text { Facilities present in } \\
\text { the schools }\end{array}$ & -0.029 & 0.296 & $>0.05$ \\
\hline School proprietorship & 0.275 & 0.000 & $<0.05^{*}$ \\
\hline
\end{tabular}

\section{Multiple correlation coefficient squared $\left(r^{2}\right)$ is 0.112} *Significant

Table 7b: Stepwise regression analysis for sexual activity showing changes in multiple regression coefficient of determination of $\left(r^{2}\right)$ with addition of different variables

\begin{tabular}{|llll|}
\hline Stages of analysis & $\left(\mathbf{R}^{2}\right)$ & $\begin{array}{l}\mathbf{R}^{2} \\
\text { Change }\end{array}$ & $\mathbf{P}$ \\
$\begin{array}{l}\text { School proprietorship } \\
\text { School proprietorship } \\
+ \text { school gender }\end{array}$ & 0.084 & 0.083 & 0.00 \\
$\begin{array}{l}\text { School proprietorship } \\
+\quad 0.095\end{array}$ & 0.094 & 0.00 \\
$\begin{array}{l}\text { sex } \\
\text { school gender }+\end{array}$ & & \\
$\begin{array}{l}\text { School proprietorship } \\
+\quad \text { school gender }+\end{array}$ & 0.103 & 0.102 & 0.00 \\
sex + social class & & & \\
Other variables & 0.111 & 0.110 & \\
& 0.112 & 0.111 & 0.00 \\
\hline
\end{tabular}


The early initiation of sexual intercourse found in this study is comparable to that reported by Meekers [12] (12.6yrs for females, 13.4yrs for males) and Odunjinrin [20] (12.3 years females). Poor economic conditions (especially with respect to the females) and peer influences have been suggested to encourage early sexual initiation amongst adolescents $[14,20]$. Sexual intercourse with multiple partners as found in this study is similar to the results of previous studies $[9,13,14,20]$.

Among the sexually active students, only $36.9 \%$ reported ever-use of condom. This low usage $(36.9 \%)$ of condom is similar to the findings by Judith [11] and Olufunmilayo et al [14] who reported $38.9 \%$ and $47.2 \%$ of everuse of condom, respectively. It was however, higher (62\%) in Meeker's study [12].

In this study $11.2 \%$ of the variation in the ever-had sexual intercourse status was explained by all the independent variables in the multiple regression analysis. It shows that, of all the variables, sex, social class and school gender of the students significantly affect their ever-had sexual intercourse status. This result agrees with the finding by Meeker [12] who found that students from low social economic class were more sexually active. This may suggest that money could be the motivation for the students in the low social class.

\section{Conclusion}

It is concluded that the prevalence of sexual intercourse is high among the students. Sexual intercourse is initiated at an early age and having multiple sexual partners is not uncommon among the adolescents. Sexual intercourse is commoner among the male and students from state schools. The use of condom is uncommon among the study population.

There is need to introduce and emphasise school-based HIV/AIDS prevention programme early in the school before the initiation of the HIV risk-related behaviour. The use of condom should be emphasised. The contents of school health HIV/AIDS prevention and control programs should be evaluated at intervals and modified to achieve effective control of HIV.

\section{References}

1. UNAIDS Global HIV/AIDS and STD surveillance, Report on the global HIV/AIDS.WHO Geneva December 2000.

2. WHO. Surveillance evaluation and forecasting. Global programme on AIDS. Slowing the spread of HIV: Agenda for the 1990's. Science. 1993; 260: $1266-1268$.

3. United Nation Population Fund. AIDS. The Right to protection. The State of the World Population 1997; 21-22.

4. Gibb D and Peckham C. AIDS in the Developing World. The Med Intern J 1993; 13-16.

5. UNICEF Publication. The growing impact of HIV Infection on women children and family life in the developing world. Children and AIDS. An Impending calamity 1990:1-24.

6. Caldwell M B, Rogers M F. Epidemiology and Transmission of HIV in children. Childhood AIDS. W B Saunders company Philadelphia, 1991:30-35.

7. Grant J P. AIDS The children's strategy. The State of the World Children 1999. (Published for UNICEF), Oxford University Press; 22.

8. Mezie-Okoye. KAP studies on HIV/AIDS in secondary school girls in Port Harcourt \& its environs. Paper presented at Medical women association of Nigeria conference, (MWAN) Onitsha, 1999.

9. Odujinrin OM and Akinkuade FO. Adolescents AIDS knowledge, attitude and beliefs about preventive practices in Nigeria. European Journal of Epidemiology. 1991; 7: 127-133.

10. Aomreore AA, Alikor EAD. Survey of knowledge of HIV infection among Senior Secondary School 3 (SSS3) Students in Port Harcourt. Nigerian Journal of Medicine. 2004; 13: 398404.

11. Judith C, Lahai-Momoh and Michael W R. HIV/AIDS Prevention related social skills and knowledge among Adolescents in Seirra Leone, West African Journal of Reproductive Health. 1997; 1: 37-43. 
12. Meekers D, Calves A E. Gender differential in Adolescent sexual activity and reproductive health risk in Cameroon. African Journal of Reproductive Health. 1999; 60-67.

13. Brabin L, Kemp J, Obunge OK, Ikimalo J, Dollimore N, Odu NN, Hart C, Briggs ND. Reproductive tract Infection \& abortion among adolescent girls in rural Nigeria. Lancet 1995; 345: 300-304: 1-16.

14. Olufumilayo I. F, Michael C, Asuzu and Oduntan S O. Survey of knowledge, attitudes and sexual practices relating to HIV Infection/AIDS among Nigeria secondary school students. Nigerian Journal of Reproductive Health. 1624.

15. Adelekan ML, Ndom RJ. Trends in prevalence \& pattern of substance use among secondary school pupils in Ilorin, Nigeria. West African Journal of Medicine. 1997; 16:157-164.

16. Ogunremi O O, Okonofua F E. Abuse of drugs among Nigeria Youths. African Journal of Psychiatry. 1997; 3:107-112.

17. Anochie I C, Nkanginieme $\mathrm{K}$ E O, Eke F, Alikor E A D. Drug abuse among secondary school students in Port Harcourt metropolis. Nigerian Medical Journal. 1999; 38-45.

18. Manual for the management of HIV infections in infants, children \& Adolescents. 1998.

19. Survey of drug use /abuse pattern in Kano state secondary school. NDLEA1992; 14-38.

20. Odunjinrin O M T. Sexual activity, contraceptive practice and abortion among Adolescences in Lagos, Nigeria. International Journal of Gynaecology and Obstetrics. 1991; 34:361-366. 